\title{
EFFECT OF ON-FARM SEED PRIMING ON YIELD AND SEED QUALITY OF BEAN (Phaseolus vulgaris L.) \\ Ahmed, H. M.I. ${ }^{1 *}$, Denise C.F. Dias ${ }^{2}$ and A. M. Moghazy ${ }^{1}$ \\ 1-Vegetable Crops Seed Production and Technology Department, Horticulture Res. Institute, Agric. Research Center, Giza, Egypt. \\ 2-Dept. de Fitotecnia, Universidade Federal de Viçosa, 36571-000 - Viçosa, MG, Brazil. \\ *Corresponding Author E-mail: hamdino@yahoo.com
}

\begin{abstract}
Two field experiments were carried out during the two summer growing seasons of 2006 and 2007, at El-Baramoon Farm, Mansoura Horticultural Research Station, Dakahlia Governorate, Egypt, to investigate the effect of on-farm seed priming for different periods in water or in molybdenum (Mo) solution on growth, yield and pod characters as well as seed yield and its quality of snap bean (Phaseolus vulgaris L.) Cv. Bronco. Nine treatments were arranged in complete randomized block design with 3 replicates.

Results indicated that priming bean seeds in Mo solution or water significantly increased the capability of the plants to produce vigorous vegetative growth expressed as plant height, number of branches and number of leaves per plant, plant fresh and dry weight as well as chlorophyll content.

All priming treatments enhanced the total green plant yield, especially priming for 9 hours in Mo solution or water. These treatments gave the highest values for yield. Seed yield and its quality were also improved as a result of using seed priming treatments.

Generally, On-farm seed priming seems to be a widely applicable technology and can be used to add to the benefits achieved by using improved modern varieties or by adoption of other improved technologies such as fertilizer or better crop protection. This low-cost, low-risk technology is good insurance for farmers by providing low-cost more options and improvements to their livelihoods.
\end{abstract}

\section{INTRODUCTION}

Common bean (Phaseolus vulgaris L.) is frequently consumed as both dry beans and immature green pods, called snap beans. Dry bean is an important food staple worldwide and provides a significant source of protein, calories, vitamins, minerals and fiber. Seeds of beans are the most important protein and mineral food sources overall the world, especially the developing countries including Egypt.

Poor germination and low seed viability are among the most serious problems in the production of bean. The use of high-quality seed with appropriate seed rate is essential to establish a suitable plant population in the field for best returns. Vigorous seeds germinate rapidly and uniformly, and are able to better withstand environmental adversity after sowing (Ajouri et al., 2004; Marwat \& Nafziger, 1990).

Good crop-stand establishment is vital in the production of annual crops from seed, because patchy stands result in low yields. Having good stands is particularly important for resource-poor farmers in developing 
countries because, even if sparse crops can be re-sown, it is expensive and can lead poor farmers into crippling debt. Good crop establishment is especially difficult in marginal environments under which many poor farmers live. Several factors, e.g., poor soils, low-quality seed, and limited availability of labor or draft power contribute to such a situation.

Speed of germination and emergence is an important limiting factor of successful crop stand establishment (Harris, 1996). Harris et al. 1999 demonstrated that on farm seed priming - soaking seeds for a certain period in water, surface-drying them and then sowing in normal fashion markedly improved the stand establishment and early vigor of chickpea. They added that rapid establishment and greater vigor also resulted in greater and faster plant development, earlier flowering and maturity, and higher yields. Moreover, these effects resulting from such simple, low-cost, low-risk intervention also had positive impacts on the wider farming system and farmers' livelihoods, and the technology has proven to be highly popular with farmers (Harris et al. 1999).

This simple technology, as expected, promoted rapid germination and emergence but was also found, in many cases, to increase seedling vigor, advanced crop development, and increased yield. Other benefits of onfarm seed priming have been observed. Musa et al. (2001) reported that priming chickpea seed for $8 \mathrm{~h}$ significantly reduced the damage caused by collar rot (Sclerotium rolfsii) in Bangladesh. Recent work in Pakistan has demonstrated that mungbean (Vigna radiata) grown from seed primed in water for $8 \mathrm{~h}$ before sowing showed significantly fewer serious symptoms of infection by Mungbean Yellow Mosaic Virus (MYMV) than a crop established without priming (Rashid et al. 2004 a). The large differences in virus-related damage were associated with significant increases in pod weight (3-fold) and grain weight (5-fold) due to priming.

Seed priming has been particularly effective in legumes. For example, yields of chickpea (Cicer arietinum) and mungbean (Vigna radiata) were increased substantially by priming seeds for $8 \mathrm{~h}$ before sowing (Harris et al. 1999; Musa et al. 2001; Rashid et al. 2004b). Yield benefits were due to a combination of better crop stands and better individual plant performance. For chickpea, Musa et al. (2001) in Bangladesh also noted that plants grown from primed seeds had significantly more $\mathrm{N}$-fixing nodules than plants grown from non-primed seeds. This effect has also been reported in cowpea (Vigna unguiculata) in Senegal by Braconnier and Bourou (2004).

In many parts of the world, legumes do not grow well because they cannot take up enough Molybdenum (Mo). It is possible, if rather expensive, to add salts such as sodium molybdate to the soil but it is also quite difficult to spread it uniformly across large areas due to the small quantities involved. Substantial yield benefits $(20-90 \%)$ can result from the addition of tiny amounts of Mo to the priming water.

Molybdenum, a micronutrient element essential for nearly all organisms, deserves special attention as a major requirement for plant growth. Mo is a constituent of nitrogenase and nitrate reductase, required for the assimilation of soil nitrates. Therefore, the function of Mo is closely related to plant nitrogen metabolism, and Mo deficiency is manifested as 
deficiency of plant N (Mendel and Hansch, 2002; Pollock et al., 2002). If symbiosis is being established, unusual proliferation of nodules is often observed when legumes are deficient in Mo, presumably due to the $\mathrm{N}$ deficiency (Marschner, 1995). However, lesser Mo content is required for nitrate reduction than for $\mathrm{N}_{2}$-fixation support (Parker and Harris, 1977). Therefore, Mo is efficiently concentrated in the nodules of Mo-deficient plants (Brodrick and Giller, 1991).

The research results available show that a low level of molybdenum in bean seeds being sown $(<1.41 \mathrm{mg}$ kg-1) results in plants of a lower weight of root nodules, yielding lower, accumulating less nitrogen, and producing seeds with $50 \%$ lower germination (Brodrick et al. 1992).

Rondon et al. (2007) indicated that bio-char enhanced biological nitrogen fixation (BNF) by common beans (Phaseolus vulgaris L.) and the primary reason for the higher BNF with bio-char additions was the greater $\mathrm{B}$ and Mo availability. They added that bean yield was increased by $46 \%$ and biomass production by $39 \%$ over the control at 90 and $60 \mathrm{~g} \mathrm{~kg}-1$ bio-char, respectively.

The aim of this work was to study the efficiency of using on-farm seed priming for different periods in water or in molybdenum (Mo) solution on enhancing growth, yield and pod characters, as well as seed yield and its quality, of snap bean plants cv. Bronco.

\section{MATERIALS AND METHODS}

Two field experiments were carried out during the two growing summer seasons of 2006 and 2007, at El Baramoon Farm of Mansoura Horticultural Research Station, Dakahlia Governorate, Egypt, to investigate the effect of on-farm seed priming for different periods and using molybdenum solutions on growth, yield and pods characters as well as seed yield and quality of snap bean plants $\mathrm{cv}$. Bronco. The soil of the experimental field was clayey in texture. Data of chemical and mechanical properties as described by Chapman and Pratt (1961) and Jakson (1965) are shown in Table (1).

Table (1): Mechanical and chemical analysis of the soil during 2006 season.

\begin{tabular}{|c|c|c|c|c|c|}
\hline Sand $\%$ & Silt $\%$ & Clay $\%$ & Tex. class & O.M. $\%$ & $\mathbf{C a C o}_{3} \%$ \\
\hline 16.72 & 24.65 & 56.35 & clayey & 1.95 & 3.13 \\
\hline Avail. N ppm & Avail P ppm & Avail K ppm & Fe ppm & EC. ds/m & pH \\
\hline 69 & 4.72 & 297 & 18.2 & 0.93 & 8.2 \\
\hline
\end{tabular}

Seeds of Bronco cv. of snap bean were divided into 9 groups; the first group did not have any treatment served as control while the remaining 8 groups were treated with different seed priming periods and molybdenum. Each experiment included 9 treatments as follows:

1- Control treatment.

2- Seed priming in water for 3 hours. 
Ahmed, H. M.I. et al.

3- Seed priming in water for 6 hours.

4- Seed priming in water for 9 hours.

5 - Seed priming in water for 12 hours.

6 - Seed priming in $50 \mathrm{ppm}$ Mo solution for 3 hours.

7- Seed priming in $50 \mathrm{ppm}$ Mo solution for 6 hours.

8- Seed priming in $50 \mathrm{ppm}$ Mo solution for 9 hours.

9- Seed priming in $50 \mathrm{ppm}$ Mo solution for 12 hours.

After the priming treatment, the seeds were spread for surface drying, and then were sown on March 15 and 18 of 2006 and 2007 seasons, respectively. A complete randomized block design with 3 replicates was followed. The plot area was $17.5 \mathrm{~m}^{2}$, which consisted of 5 rows, each row 5 $\mathrm{m}$ in length and $70 \mathrm{~cm}$ width. Three seeds were sown per hill at $15 \mathrm{~cm}$ apart, and the growing seedlings were thinned to one plant after 20 days from sowing. Surface irrigation was applied and other agricultural practices used in accordance with the recommendations of the Ministry of Agriculture.

Recorded data was from samples, each of 5 plants, from each plot taken at 50 days after sowing (flowering stage) to determine the following data:

- Plant height $(\mathrm{cm})$, number of branches per plant, number of leaves per plant, leaf area (measured by Li-300 leaf area meter produced by Li-Cor, Pinclivania), total fresh and dry weight of vegetative part of plant (leaves + stem).

- Total chlorophyll of the third leaf from top measured by using chlorophyll meter (SPAD).

- Total pod yield. During harvest, the green pods produced were collected and the total pods yield was calculated at the end of the harvesting season.

- Pod characters: A random sample of 20 pods was taken and average pod length, diameter and weight were measured.

- At second harvest, random samples of green pods were taken from each plot and oven-dried at $70 \mathrm{C}^{\circ}$ until constant, and the dry matter was then finely ground and analyzed to determine nitrogen, phosphorus and potassium concentrations by the methods described by Watanabe and Olsen (1965), and Jackson (1967) respectively; and total protein was determined in dry pods using the method of A.O.A.C. (1975).

- At seed maturity stage; plants were harvested, dry seeds were manually extracted and total dry seed yield ( $\mathrm{kg} / \mathrm{fed}$.) was calculated, seed index and germination percentage (GP) were measured according to the ISTA rules (ISTA, 1999). Mean time to germination in days (MGT) was calculated according to the formula MGT $=\Sigma \mathrm{nd} / \mathrm{N}$ where $\mathrm{n}$ is the number of germinated seed on each day, $d$ the number of days from the beginning of the test, and $\mathrm{N}$ the total number of germinated seeds (Edwards and Sundstrom, 1987).

The obtained data were subjected to statistical analysis of variance according to Gomez and Gomez (1984) and the treatment means were compared using the Duncan Multiple Range test as published by Duncan (1965). 


\section{RESULTS AND DISCUSSION}

\section{1- Vegetative Growth}

Data presented in Tables 2 and 3 demonstrate that seed priming significantly stimulated the vegetative growth characters of plants, when compared with the untreated plants (control) in both the two seasons. Moreover, priming with molybdenum was superior to water priming.

Regardless of the priming solution, priming for 9 hours proved to be a more effective treatment in enhancing the vegetative growth parameters of bean plants.

Table (2): Effect of seed priming on plant height, number of branches and leaves per plant as well as leaf area of bean plants during 2006 and 2007 seasons.

\begin{tabular}{|c|c|c|c|c|c|c|c|c|}
\hline Seasons & \multicolumn{4}{|c|}{2006} & \multicolumn{4}{|c|}{2007} \\
\hline \begin{tabular}{|c|} 
Characters \\
Treatments
\end{tabular} & $\begin{array}{l}\text { Plant } \\
\text { Height } \\
\text { (cm) }\end{array}$ & $\begin{array}{c}\text { No. of } \\
\text { Branches } \\
\text { / plant }\end{array}$ & $\begin{array}{l}\text { No. of } \\
\text { Leaves } \\
\text { / plant }\end{array}$ & $\begin{array}{l}\text { Leaf } \\
\text { Area } \\
\text { / plant } \\
\left(\mathrm{cm}^{2}\right) \\
\end{array}$ & $\begin{array}{l}\text { Plant } \\
\text { Height } \\
(\mathrm{cm})\end{array}$ & $\begin{array}{c}\text { No. of } \\
\text { Branches } \\
\text { / plant }\end{array}$ & $\begin{array}{l}\text { No. of } \\
\text { Leaves } \\
\text { / plant }\end{array}$ & $\begin{array}{c}\text { Leaf } \\
\text { Area } \\
/ \text { plant } \\
\left(\mathrm{cm}^{2}\right) \\
\end{array}$ \\
\hline Control & $30.3 \mathrm{e}$ & $3.87 \mathrm{e}$ & $10.3 \mathrm{~b}$ & $156 \mathrm{a}$ & $29.6 \mathrm{e}$ & $3.77 \mathrm{e}$ & $9.7 \mathrm{~d}$ & $147 \mathrm{e}$ \\
\hline \begin{tabular}{|l|}
$\begin{array}{l}\text { Priming in } \\
\text { water for } \\
\text { h. }\end{array}$ \\
\end{tabular} & $31.7 \mathrm{de}$ & $4.30 \mathrm{~d}$ & $11.3 \mathrm{ab}$ & $160 \mathrm{a}$ & $31.1 \mathrm{de}$ & $4.03 \mathrm{e}$ & $11.0 \mathrm{bc}$ & $163 \mathrm{~d}$ \\
\hline $\begin{array}{l}\begin{array}{l}\text { Priming in } \\
\text { water for } 6 \\
\text { h. }\end{array} \\
\end{array}$ & $32.9 \mathrm{~cd}$ & $4.93 \mathrm{c}$ & $11.0 \mathrm{ab}$ & $166 \mathrm{a}$ & $32.4 \mathrm{~cd}$ & $4.80 \mathrm{~d}$ & $10.7 \mathrm{c}$ & $167 \mathrm{~cd}$ \\
\hline $\begin{array}{|lr|}\begin{array}{l}\text { Priming } \\
\text { water }\end{array} \\
\text { h. }\end{array}$ & $35.5 \mathrm{ab}$ & $5.43 \mathrm{~b}$ & $12.3 \mathrm{a}$ & $167 \mathrm{a}$ & $34.6 \mathrm{ab}$ & $5.27 \mathrm{bc}$ & $12.0 \mathrm{a}$ & $182 \mathrm{a}$ \\
\hline $\begin{array}{|lr|}\begin{array}{l}\text { Priming } \\
\text { water }\end{array} & \text { in } \\
\text { 12h. } & \text { for } \\
\end{array}$ & $35.0 \mathrm{ab}$ & $5.37 \mathrm{~b}$ & $11.0 \mathrm{ab}$ & $170 \mathrm{a}$ & $34.9 \mathrm{ab}$ & $5.10 \mathrm{~cd}$ & $10.7 \mathrm{c}$ & $182 \mathrm{a}$ \\
\hline $\begin{array}{|lr|}\text { Priming } & \text { in } \\
50 \mathrm{ppm} & \mathrm{Mo} \\
\text { solution } & \text { for } \\
3 \mathrm{~h} . & \\
\end{array}$ & $34.1 \mathrm{bc}$ & $5.27 \mathrm{bc}$ & $11.3 \mathrm{ab}$ & $172 \mathrm{a}$ & $33.6 \mathrm{bc}$ & $5.07 \mathrm{~cd}$ & $11.0 \mathrm{bc}$ & $170 \mathrm{bc}$ \\
\hline $\begin{array}{|lr|}\text { Priming } & \text { in } \\
50 \mathrm{ppm} & \mathrm{Mo} \\
\text { solution } & \text { for } \\
6 \mathrm{~h} . & \\
\end{array}$ & $35.9 \mathrm{a}$ & $5.43 \mathrm{~b}$ & $11.7 \mathrm{ab}$ & $175 a$ & $36.1 \mathrm{a}$ & $5.47 \mathrm{ab}$ & $11.7 \mathrm{ab}$ & $172 \mathrm{~b}$ \\
\hline $\begin{array}{|lr|}\text { Priming } & \text { in } \\
50 \mathrm{ppm} & \mathrm{Mo} \\
\text { solution } & \text { for } \\
9 \mathrm{~h} . & \\
\end{array}$ & $36.0 \mathrm{a}$ & $6.00 \mathrm{a}$ & $12.3 \mathrm{a}$ & $181 \mathrm{a}$ & $35.9 \mathrm{a}$ & $5.77 \mathrm{a}$ & $11.3 \mathrm{ab}$ & $184 a$ \\
\hline $\begin{array}{|lr|}\text { Priming } & \text { in } \\
50 \mathrm{ppm} & \mathrm{Mo} \\
\text { solution } & \text { for } \\
12 \mathrm{~h} . & \\
\end{array}$ & $35.0 \mathrm{ab}$ & $5.47 \mathrm{~b}$ & $11.7 \mathrm{ab}$ & $182 \mathrm{a}$ & $35.1 \mathrm{ab}$ & $5.5 \mathrm{ab}$ & $10.7 \mathrm{c}$ & $184 \mathrm{a}$ \\
\hline
\end{tabular}
different, using Duncan's Multiple Range Test at $5 \%$ level.

The highest values of plant height, number of branches and leaves per plant, plant fresh weight, plant dry weight, leaf area and the total chlorophyll content were produced by priming bean seeds for 9 hours in 50 ppm of Mo solution. 
Table (3): Plant fresh and dry weight as well as total chlorophyll of bean plants in relation seed priming treatments during 2006 and 2007 seasons.

\begin{tabular}{|c|c|c|c|c|c|c|}
\hline Seasons & & 2006 & & & 2007 & \\
\hline \begin{tabular}{|l|} 
Characters \\
Treatments
\end{tabular} & $\begin{array}{l}\text { Plant } \\
\text { Fresh } \\
\text { Weight } \\
\text { (g) }\end{array}$ & $\begin{array}{c}\text { Plant Dry } \\
\text { weight } \\
\text { (g) }\end{array}$ & $\begin{array}{c}\text { Total } \\
\text { Chlorophyll } \\
\text { (SPAD) }\end{array}$ & $\begin{array}{l}\text { Plant Fresh } \\
\text { Weight } \\
(g)\end{array}$ & $\begin{array}{l}\text { Plant Dry } \\
\text { weight } \\
\text { (g) }\end{array}$ & $\begin{array}{c}\text { Total } \\
\text { Chlorophyll } \\
\text { (SPAD) }\end{array}$ \\
\hline Control & $37.0 \mathrm{e}$ & $4.04 \mathrm{~b}$ & $37.2 \mathrm{~d}$ & $36.3 \mathrm{e}$ & $3.96 \mathrm{~h}$ & $37.7 \mathrm{~d}$ \\
\hline $\begin{array}{l}\text { Priming in water for } \\
3 \mathrm{~h} \text {. }\end{array}$ & $40.3 \mathrm{~d}$ & $4.45 b$ & $39.8 \mathrm{c}$ & $39.7 d$ & $4.28 \mathrm{~g}$ & $39.5 \mathrm{c}$ \\
\hline $\begin{array}{l}\text { Priming in water for } \\
6 \mathrm{~h} \text {. }\end{array}$ & $42.7 \mathrm{c}$ & $6.00 \mathrm{a}$ & $39.8 \mathrm{c}$ & $42.0 \mathrm{c}$ & $5.15 \mathrm{e}$ & $39.7 c$ \\
\hline $\begin{array}{l}\text { Priming in water for } \\
9 \mathrm{~h} \text {. }\end{array}$ & $45.0 \mathrm{ab}$ & $5.95 \mathrm{a}$ & $40.3 \mathrm{c}$ & $43.9 \mathrm{~b}$ & $5.65 \mathrm{~cd}$ & $40.1 \mathrm{c}$ \\
\hline $\begin{array}{l}\text { Priming in water for } \\
12 \mathrm{~h} \text {. }\end{array}$ & $44.5 \mathrm{bc}$ & $5.90 \mathrm{a}$ & $40.8 \mathrm{c}$ & $43.5 \mathrm{bc}$ & $5.56 \mathrm{~d}$ & $40.3 \mathrm{c}$ \\
\hline \begin{tabular}{|l} 
Priming in $50 \mathrm{ppm}$ \\
Mo solution for $3 \mathrm{~h}$.
\end{tabular} & $43.0 \mathrm{c}$ & $5.51 \mathrm{a}$ & $42.1 \mathrm{~b}$ & $41.7 \mathrm{c}$ & $5.03 \mathrm{f}$ & $42.6 \mathrm{~b}$ \\
\hline $\begin{array}{l}\text { Priming in } 50 \mathrm{ppm} \\
\text { Mo solution for } 6 \mathrm{~h} \text {. }\end{array}$ & $43.8 \mathrm{bc}$ & $5.66 \mathrm{a}$ & $43.6 \mathrm{~b}$ & $42.3 \mathrm{bc}$ & $5.70 \mathrm{c}$ & $43.2 \mathrm{~b}$ \\
\hline $\begin{array}{l}\text { Priming in } 50 \mathrm{ppm} \\
\text { Mo solution for } 9 \mathrm{~h} \text {. }\end{array}$ & $46.8 \mathrm{a}$ & $6.30 \mathrm{a}$ & $46.3 \mathrm{a}$ & $45.9 \mathrm{a}$ & $6.03 \mathrm{a}$ & $46.0 \mathrm{a}$ \\
\hline \begin{tabular}{|l|} 
Priming in 50 ppm \\
Mo solution for $12 \mathrm{~h}$.
\end{tabular} & $15.1 \mathrm{ab}$ & $6.05 \mathrm{a}$ & $46.0 \mathrm{a}$ & $44.1 \mathrm{~b}$ & $5.87 b$ & $45.9 \mathrm{a}$ \\
\hline
\end{tabular}

Values within the same column followed by the same letters are not significantly different, using Duncan's Multiple Range Test at $5 \%$ level.

On the other hand, some reports concluded that seed priming promoted the vegetative growth of different crops for instance; Harris et al. (1999) found that hydropriming enhanced seedling establishment and early vigor of chickpea. Arif and Tariqjan (2008) found that priming enhanced the different vegetative growth characters of soybean.

Results reported by numerous authors also show favorable effects of using molybdenum on the vegetative growth of bean for example, Padma et al. (1989) and Deka and Shadeque (1991) recorded an increase in plant height, leaf area and number of leaves per plant.

\section{2- Total Yield and Pod Characters}

Significant increases were detected in the total green pod yield and pod characters expressed as average pod length, and fresh weight, from plants which received priming treatments, as compared to the control, as presented in Table 4, but at the same time there were no significant differences in the pod diameter in both seasons. Data also show that priming in $50 \mathrm{ppm}$ Mo was significantly superior to other treatments, i.e, water priming or control. The superior results of molybdenum as a priming tool may be attributed to producing plants with the highest branch numbers, widest leaf area and higher total chlorophyll content in leaves as presented in Tables 2 and 3. These plants apparently possessed higher capability of photosynthesis. This would in turn build higher yield of carbohydrates which gave rise to more cell division and enlargement, inducing more vegetative vigorous plants, and finally lead to produce more total yield.

Priming for 9 or 12 hours either in water or molybdenum proved to be the best treatments in increasing yield of bean. There is a great deal of 
evidence that on-farm seed priming is an effective method for resource-poor farmers to increase yields. Although there is some evidence that the initial germination response to priming is greater in crops and situations where germination is slower (which is often correlated with seed size (Harris and Mottram, 2005), priming seems to be appropriate across a wide range of legumes. The yield gains result from earlier, faster germination and emergence, more vigorous early growth, earlier flowering, and hastened maturity (e.g., Harris 1996, 2003; Harris et al. 1999, 2001a; Musa et al. 2001).

Table (4): Total yield and pod characters of bean plants as affected by seed priming during 2006 and 2007 seasons.

\begin{tabular}{|c|c|c|c|c|c|c|c|c|}
\hline Seasons & \multicolumn{4}{|c|}{2006} & \multicolumn{4}{|c|}{2007} \\
\hline Treatments & \begin{tabular}{|c|} 
Total \\
Yield \\
(ton/fed)
\end{tabular} & $\begin{array}{l}\text { Average } \\
\text { Pod } \\
\text { Length } \\
\text { (cm) }\end{array}$ & \begin{tabular}{|c|} 
Average \\
Pod \\
Diameter \\
(cm)
\end{tabular} & $\begin{array}{l}\text { Average } \\
\text { Pod } \\
\text { Weight } \\
\text { (g) }\end{array}$ & \begin{tabular}{|c|} 
Total \\
Yield \\
(ton/fed)
\end{tabular} & $\begin{array}{c}\text { Average } \\
\text { Pod } \\
\text { Length } \\
\text { (cm) }\end{array}$ & \begin{tabular}{|c|} 
Average \\
Pod \\
Diameter \\
$(\mathbf{c m})$
\end{tabular} & $\begin{array}{l}\text { Average } \\
\text { Pod } \\
\text { Weight } \\
\text { (g) }\end{array}$ \\
\hline Control & $3.58 \mathrm{e}$ & $9.70 \mathrm{~d}$ & $0.75 \mathrm{a}$ & $3.95 \mathrm{~d}$ & $3.52 \mathrm{~h}$ & $9.5 \mathrm{~d}$ & $0.75 \mathrm{a}$ & $4.00 \mathrm{~d}$ \\
\hline $\begin{array}{l}\text { Priming in } \\
\text { water for } 3 \mathrm{~h} .\end{array}$ & $4.80 \mathrm{~d}$ & $10.6 \mathrm{c}$ & $0.79 \mathrm{a}$ & $4.25 \mathrm{c}$ & $4.73 \mathrm{~g}$ & $10.6 \mathrm{c}$ & $0.77 \mathrm{a}$ & $4.25 \mathrm{c}$ \\
\hline $\begin{array}{l}\text { Priming in } \\
\text { water for } 6 \mathrm{~h} \text {. }\end{array}$ & $5.13 c$ & $11.0 \mathrm{bc}$ & $0.80 a$ & $4.30 \mathrm{c}$ & $5.05 \mathrm{f}$ & $10.6 \mathrm{c}$ & $0.79 \mathrm{a}$ & $4.28 \mathrm{c}$ \\
\hline $\begin{array}{l}\text { Priming in } \\
\text { water for } 9 \mathrm{~h} .\end{array}$ & $5.78 \mathrm{a}$ & $11.5 \mathrm{ab}$ & $0.77 \mathrm{a}$ & $4.75 a$ & $5.62 \mathrm{c}$ & $11.5 \mathrm{a}$ & $0.80 a$ & $4.78 \mathrm{a}$ \\
\hline $\begin{array}{l}\text { Priming in } \\
\text { water for } 12 \mathrm{~h} .\end{array}$ & $5.73 \mathrm{a}$ & $11.2 \mathrm{ab}$ & $0.79 a$ & $4.72 \mathrm{a}$ & $5.67 \mathrm{~b}$ & $11.1 \mathrm{~b}$ & $0.79 \mathrm{a}$ & $4.68 \mathrm{a}$ \\
\hline $\begin{array}{l}\text { Priming in } 50 \\
\text { ppm Mo } \\
\text { solution for } 3 \\
\text { h. } \\
\end{array}$ & $5.40 \mathrm{~b}$ & $11.0 \mathrm{bc}$ & $0.77 \mathrm{a}$ & $4.47 \mathrm{~b}$ & $5.31 \mathrm{e}$ & $10.8 \mathrm{c}$ & $0.78 \mathrm{a}$ & $4.45 \mathrm{~b}$ \\
\hline $\begin{array}{l}\text { Priming in } 50 \\
\text { ppm Mo } \\
\text { solution for } 6 \\
\text { h. }\end{array}$ & $5.44 \mathrm{~b}$ & $11.2 \mathrm{ab}$ & $0.79 a$ & $4.50 \mathrm{~b}$ & $5.38 \mathrm{~d}$ & $11.1 \mathrm{~b}$ & $0.80 \mathrm{a}$ & $4.45 \mathrm{~b}$ \\
\hline $\begin{array}{l}\text { Priming in } 50 \\
\text { ppm Mo } \\
\text { solution for } 9 \\
\text { h. }\end{array}$ & $5.84 \mathrm{a}$ & $11.6 \mathrm{a}$ & $0.78 \mathrm{a}$ & $4.77 \mathrm{a}$ & $5.79 \mathrm{a}$ & $11.6 \mathrm{a}$ & $0.82 \mathrm{a}$ & $4.80 \mathrm{a}$ \\
\hline $\begin{array}{l}\text { Priming in } 50 \\
\text { ppm Mo } \\
\text { solution for } \\
12 \mathrm{~h} .\end{array}$ & $5.83 a$ & $11.4 \mathrm{ab}$ & $0.80 \mathrm{a}$ & $4.72 \mathrm{a}$ & $5.79 \mathrm{a}$ & $11.2 \mathrm{~b}$ & $0.79 \mathrm{a}$ & $4.70 \mathrm{a}$ \\
\hline
\end{tabular}

Values within the same column followed by the same letters are not significantly different, using Duncan's Multiple Range Test at $5 \%$ level.

However, there are benefits beyond those due to enhanced general vigor or changes in phenology. Musa et al. (2001) and Rashid et al. (2004) reported that crops from primed seeds showed fewer symptoms of disease and that disease-related yield losses were smaller in primed crops. It was not possible in either case to rule out the possibility that disease resistance was the result of 'escape' or avoidance of infection due to earliness, in the case of mungbean and MYMV disease. 


\section{3- Seed Yield and Quality}

Data presented in Table 5 show the effect of seed priming on seed yield and quality expressed as, seed index, germination percentage, and mean time to germination (germination rate) of snap bean plants.

Regarding the effect of the treatments on seed yield, it is obvious that priming treatments had highly promotional effects on seed yield. Priming in Mo solution for 9 hours gave the best results in this regard, followed by priming for 12 hours in Mo solution, in both seasons.

There is a slight difference between treatment effects on seed index of bean plants. However, all treatments were superior to control treatment and priming for 9 hours either in water or in $50 \mathrm{ppm}$ Mo solution was the best treatment in both seasons.

Germination percentage as a seed quality indicator responded significantly to the priming treatments in water or Mo solution, for the different periods .Priming bean seeds in $50 \mathrm{ppm}$ Mo solution for 12 hours gave the best result in this regard in 2006 season, while priming in water for 6 hours shared the same rank for the 2007 season.

Data presented in Table 5 show that primed bean seeds in different treatments were characterized by a progressive reduction in mean germination time (MGT) as compared to non-primed seeds. Priming treatments shortened MGT by more than one day in some treatments.

Results reported by numerous authors show a favorable effect of molybdenum on seed yield and structural yield components in bean. The highest increases in seed yield were recorded following the application of 76$90 \mathrm{~g} \mathrm{Mo}$ ha-1. Compared to the control, Vieira et al. 1996 recorded a $40 \%$ seed yield increase. Reports by Correa et al. 1990 showed that molybdenum itself increases the number of pods and seeds per plant, and number of seeds per pod .Deka and Shadeque (1991) recorded an increase in pods yield per plant.

The improved seed yield and quality of primed seed from treated plots may be due to early and improved emergence of the primed plots that ultimately resulted in higher yield. Similar arguments were made by Sharma et al. (1993), who attributed higher yield to early floral initiation, more flowers and pods per plant in salicylic acid-primed seed. The resulting improved stand establishment due to priming can reportedly increase drought tolerance, reduce pest damage and increase crop yield (Harris et al., 1999; Musa et al., 1999; Harris et al., 2000). The increase in yield of primed seed plots may be due to the fact that primed seed emerge faster and more uniformly and seedlings grow more vigorously, leading to a wide range of phenological and yield-related benefits (Harris et al., 2000).

\section{4- Chemical Content of Green Pods}

Data in Table 6 indicate that total nitrogen, phosphorus and total protein content were higher in pods produced from plants primed with water or Mo solution than those of pods produced from untreated plants in the two seasons. There were no significant effects on the potassium content in pods of plants treated or untreated. 
J. Agric. Sci. Mansoura Univ., 34 (5), May, 2009 
Dry bean is an important food staple worldwide and provides a significant source of protein, calories, vitamins, minerals, and fiber (Akcin, 1988). In this connection, it should be mentioned that all priming treatments either in water or Mo solution and for different periods of $3,6,9$ or 12 hours increased protein content of beans significantly over the control treatment which recorded 21.8 and $21.1 \%$ protein for the first and second seasons respectively, while priming in Mo solution for 9 hours recorded 24.1 and 24\% protein for the first and second seasons, respectively.

Table 6: Effect of seed priming treatments on chemical content of green pod of bean plants during 2006 and 2007 seasons.

\begin{tabular}{|c|c|c|c|c|c|c|c|c|}
\hline Seasons & & & 2006 & & & 200 & & \\
\hline Characters & $\begin{array}{r}\mathrm{Ma} \\
(\mathrm{g} / 10\end{array}$ & $\begin{array}{l}\text { ronutrie } \\
\text { g dry w }\end{array}$ & $\begin{array}{l}\text { nts } \\
\text { eigh) }\end{array}$ & Total Protein & $\begin{array}{r}\mathrm{Ma} \\
(\mathrm{g} / 10\end{array}$ & $\begin{array}{l}\text { cronutrie } \\
0 \text { g dry w }\end{array}$ & $\begin{array}{l}\text { nts } \\
\text { eigh) }\end{array}$ & Total \\
\hline Treatments & $\mathbf{N}$ & $\mathbf{P}$ & $\mathbf{K}$ & & $\mathbf{N}$ & $\mathbf{P}$ & K & (\%) \\
\hline Control & $2.86 \mathrm{f}$ & $0.559 \mathrm{i}$ & $3.67 \mathrm{a}$ & $21.8 \mathrm{f}$ & $2.71 \mathrm{f}$ & $0.578 \mathrm{i}$ & $3.79 \mathrm{a}$ & $21.1 \mathrm{~h}$ \\
\hline $\begin{array}{l}\text { Priming in water for } \\
3 \mathrm{~h} \text {. }\end{array}$ & $3.13 \mathrm{e}$ & $0.582 \mathrm{~g}$ & $3.76 \mathrm{a}$ & $22.2 \mathrm{e}$ & $3.42 \mathrm{c}$ & $0.591 \mathrm{~h}$ & $3.81 \mathrm{a}$ & $21.9 \mathrm{~g}$ \\
\hline $\begin{array}{l}\text { Priming in water for } \\
6 \mathrm{~h} \text {. }\end{array}$ & $3.15 \mathrm{e}$ & $0.605 \mathrm{e}$ & $3.80 \mathrm{a}$ & $22.8 \mathrm{~d}$ & $3.43 \mathrm{c}$ & $0.601 \mathrm{f}$ & $3.82 \mathrm{a}$ & $22.6 \mathrm{f}$ \\
\hline $\begin{array}{l}\text { Priming in water for } \\
9 \mathrm{~h} \text {. }\end{array}$ & $3.25 \mathrm{~d}$ & $0.591 \mathrm{f}$ & $3.77 \mathrm{a}$ & $23.3 \mathrm{c}$ & $3.12 \mathrm{e}$ & $0.609 \mathrm{e}$ & $3.83 \mathrm{a}$ & $23.1 \mathrm{e}$ \\
\hline $\begin{array}{l}\text { Priming in water for } \\
12 \mathrm{~h} \text {. }\end{array}$ & $3.30 \mathrm{c}$ & $0.612 \mathrm{c}$ & $3.77 \mathrm{a}$ & $23.3 \mathrm{c}$ & $3.17 \mathrm{e}$ & $0.637 b$ & $3.82 \mathrm{a}$ & $23.2 \mathrm{e}$ \\
\hline $\begin{array}{l}\text { Priming in } 50 \mathrm{ppm} \\
\text { Mo solution for } 3 \mathrm{~h} \text {. }\end{array}$ & $3.22 \mathrm{~d}$ & $0.615 \mathrm{~b}$ & $3.78 \mathrm{a}$ & $23.7 b$ & $3.12 \mathrm{e}$ & $0.628 \mathrm{c}$ & $3.81 \mathrm{a}$ & $23.5 \mathrm{~d}$ \\
\hline $\begin{array}{l}\text { Priming in } 50 \mathrm{ppm} \\
\text { Mo solution for } 6 \mathrm{~h} \text {. }\end{array}$ & $3.40 \mathrm{~b}$ & $0.571 \mathrm{~h}$ & $3.77 \mathrm{a}$ & $23.8 \mathrm{~b}$ & $3.33 \mathrm{~d}$ & $0.597 \mathrm{~g}$ & $3.82 \mathrm{a}$ & $23.7 c$ \\
\hline $\begin{array}{l}\text { Priming in } 50 \mathrm{ppm} \\
\text { Mo solution for } 9 \mathrm{~h} \text {. }\end{array}$ & $3.52 \mathrm{a}$ & $0.623 \mathrm{a}$ & $3.79 \mathrm{a}$ & $24.1 \mathrm{a}$ & $3.90 \mathrm{a}$ & $0.639 \mathrm{a}$ & $3.81 \mathrm{a}$ & $24.0 \mathrm{a}$ \\
\hline \begin{tabular}{|l} 
Priming in $50 \mathrm{ppm}$ \\
Mo solution for $12 \mathrm{~h}$.
\end{tabular} & $3.50 \mathrm{a}$ & $0.609 \mathrm{~d}$ & $3.75 \mathrm{a}$ & $24.0 \mathrm{a}$ & $3.80 \mathrm{~b}$ & $0.619 \mathrm{~d}$ & $3.81 \mathrm{a}$ & $23.9 \mathrm{~b}$ \\
\hline
\end{tabular}

\section{CONCLUSION}

In many areas, germination and subsequent seedling growth can be inhibited by adverse conditions in the field. Priming is helpful in reducing the risk of poor stand establishment under a wide range of environmental conditions. Priming is a simple and useful technique for enhancing seedling emergence rate and percentage of germination of bean. These effects can improve seedling establishment and field performance of this important food legume.

\section{REFERENCES}

Ajouri, A., A. Haben and M. Becker. (2004). Seed priming enhances germination and seedling growth of barley under conditions of $P$ and Zn deficiency. Journal of Plant Nutrition and Soil Science, 167: 630636. 
Akcin, A. (1988). A research on the effects of fertilization, sowing date and row spacing on seed yield of various dry bean cultivars grown under Erzurum ecological conditions and their phonologic, morphologic and technological characteristics Erzurum. Pub. Fac. Agric. 157:1-112.

A.O.A.C. (1975). Official Methods of Analysis Chemists. 12 th Ed. A.O.A.C., Washington D.C., USA.

Arif, M. and M. Tariqjan (2008). Seed priming improves emergence and yield of soybean. Pak. J. Bot., 40(3):1169-1177.

Braconnier, S. and S. Bourou (2004) 'Etude du pr'e-trempage des graines de ni'eb'e dans l'eau comme solution technique simple pour am'eliorer la tol'erance 'a la s'echeresse du ni'eb'e.' (Centre d'etude r'egional pour l'am'elioration de l'adaptation 'a la s'echeresse (CERAAS): Thies, Senegal)

Brodrick, S. J. and K. E. Giller (1991). Root nodules efficient scavengers of molybdenum for $\mathrm{N} 2$ fixation. J. Exp. Bot., 42, 679-686.

Brodrick, S.J., M.K. Sakala and K.E Giller (1992). Molybdenum reserves of seed and growth and N2 fixation by Phaseolus vulgaris L. Biology \& Fertility of Solis 13 (1), 39-44.

Chapman, H.D. and P.F. Pratt. (1961). Methods of analyses for soil, plant and water, Univ. of California Davis Fac. Agric.

Correa, J.R.V., A.J. Netto, P.M.-de Rezende. and LA-de-B Andrade (1990). Effects of Rhizobium, molybdenum and cobalt on Phaseolus vulgaris cv. Carioca. Pesquisa-Agropecuaria-Brasileira 25 (4), 513-519.

Deka, B.C.and A. Shadeque (1991). Influence of micronutrient on growth and yield of French bean var. Pusa Parvati Seeds \& Farms 17 (11-12), 1718.

Duncan, D.B. (1965). Multiple Range and Multiple F. Test. Biometrics, 11:142.

Edwards, R.L. and F.J. Sundstrom (1987). After ripening and harvesting effects on Tabasco pepper seed germination performance. HortScience, 22:473-475.

Gomez, K.A. and A.A. Gomez (1984). Statical Procedure for Agriculture Research. 2nd Ed. Ghon Willy and Sons.

Harris, D. (1996). The effects of manure, genotype, seed priming, depth and date of sowing on the emergence and early growth of Sorghum bicolor (L.) Moench in semi-arid Botswana. Soil and Tillage Research 40, 7388.

Harris, D. (2003). Reducing risk and increasing yields from rainfed crops in Africa using 'on-farm' seed priming. In 'Harnessing crop technologies to alleviate hunger and poverty in Africa-Abstracts'. Nairobi 2003, pp 87-88, (African Crop Science Society)

Harris, D. and A. Mottram (2005). Practical hydration of seeds of tropical crops: 'on-farm' seed priming. In 'Seed science and technology: trends and advances'. (Ed. AS Basra) pp. 724-734. (The Howarth Press: New York) 
Harris, D., A. Joshi, P.A. Khan, P. Gothkar and P.S. Sodhi (1999). On-farm seed priming in semi-arid agriculture: development and evaluation in maize, rice and chickpea in India using participatory methods. Experimental Agriculture 35, 15-29.

Harris, D., R.S. Tripathi and A. Joshi (2000). On farm seed priming to improve crop establishment and yield in direct-seeded rice, in IRRI: International Workshop on Dry-seeded Rice Technology; held in Bangkok, 25-28 January 2000. The International Rice Research Institute, Manila, The Philippines, pp.164.

Harris, D., A.K. Pathan, P. Gothkar, A. Joshi, W. Chivasa and P. Nyamudeza (2001). On-farm seed priming: using participatory methods to revive and refine a key technology. Agricultural Systems 69,151-164.

ISTA (1999). International Rules for Seed Testing. Seed Science and Technology, 27:1-333.

Jackson, M.L., (1967). Soil Chemical Analysis and Advanced Course. Publ. By Author, Madison, Wisconsin, USA.

Marschner, H. (1995). Mineral nutrition of higher plants. Academic Press, San Diego. Page. 229-299.

Marwat, K.B. and E.D. Nafziger (1990). Cocklebur and Velvet leaf interference with soybean grown at different densities and planting patterns. Agron. J., 82(3): 531-534.

Mendel, R. R. and R. Hansch (2002). Molybdoenzymes and molybdenum cofactor in plants. J. Exp. Bot., 53, 1689-1698.

Musa, A.M., C. Johansen, J. Kumar and D. Harris (1999). Response of chickpea to seed priming in the high barind tract of Bangladesh. International Chickpea and Pigeonpea Newsletter, 6: 20-22.

Musa, A.M., D. Harris D., C. Johansen and J. Kumar (2001) Short duration chickpea to replace fallow after aman rice: the role of on-farm seed priming in the High Barind Tract of Bangladesh. Experimental Agriculture 37, 509-521.

Padma, M., S.A. Reddy and R.S.Babu (1989). Effect of foliar sprays of molybdenum (Mo) and boron (B) on vegetative growth and dry matter production of French bean (Phaseolus vulgaris L.). J. Res. APAU 17 (1), 87-89.

Parker, D. R. and H. B. Harris (1977). Yield leaf nitrogen of nodulating soybeans as affected by nitrogen and molybdenum. Agron. J., 69, 551554.

Pollock, V. V., Conover, R. C., Johnson, M. K, and M. J. Barber (2002). Bacterial expression of the molybdenum domain of assimilate nitrate reductase: Production of both the functional molybdenum-containing domain and the nonfunctional tungsten analog. Arch. Biochem. Biophys, 2, 237-248.

Rashid, A, D. Harris, P.A. Hollington and S. Ali (2004a) On-farm seed priming reduces yield losses of mungbean (Vigna radiata) associated with Mungbean Yellow Mosaic Virus in the North West Frontier Province of Pakistan. Crop Protection 23, 1119-1124. 
Rashid, A, D. Harris, P.A. Hollington and M. Rafiq (2004b) Improving the yield of mungbean (Vigna radiata) in the NorthWest Frontier Province of Pakistan using on-farm seed priming. Experimental Agriculture 40, 233-244.

Sharma, R., E.H. Kwon and K.P. Ganeshan (1993). Response of soybean (Glycine max L). Merril to seed priming with salicylic acid. Indian Journal of Ecology, 20: 27-29.

Rondon, M. A.;J. Lehmann.; J. Ramirez and M. Hurtado, (2007) Biological nitrogen fixation by common beans (Phaseolus vulgaris L.) increases with bio-char additions. Biology and Fertility of Soils. 43(6): 699-708.

Vieira, C., G.A.Araujo and P.G Berger (1996). Intercropping of beans and maize. XII. Nitrogen and molybdenum fertilizers. Revista-Ceres 43, 785-791.

Watanabe, F.S. and S.R. Olsen (1965). Test of an ascorbic acid method for determine phosphorus in 3 water and $\mathrm{Na} \mathrm{HCO}$ extract from soil. Soil Sci. Soc. Am Proc., 29: 677-678.

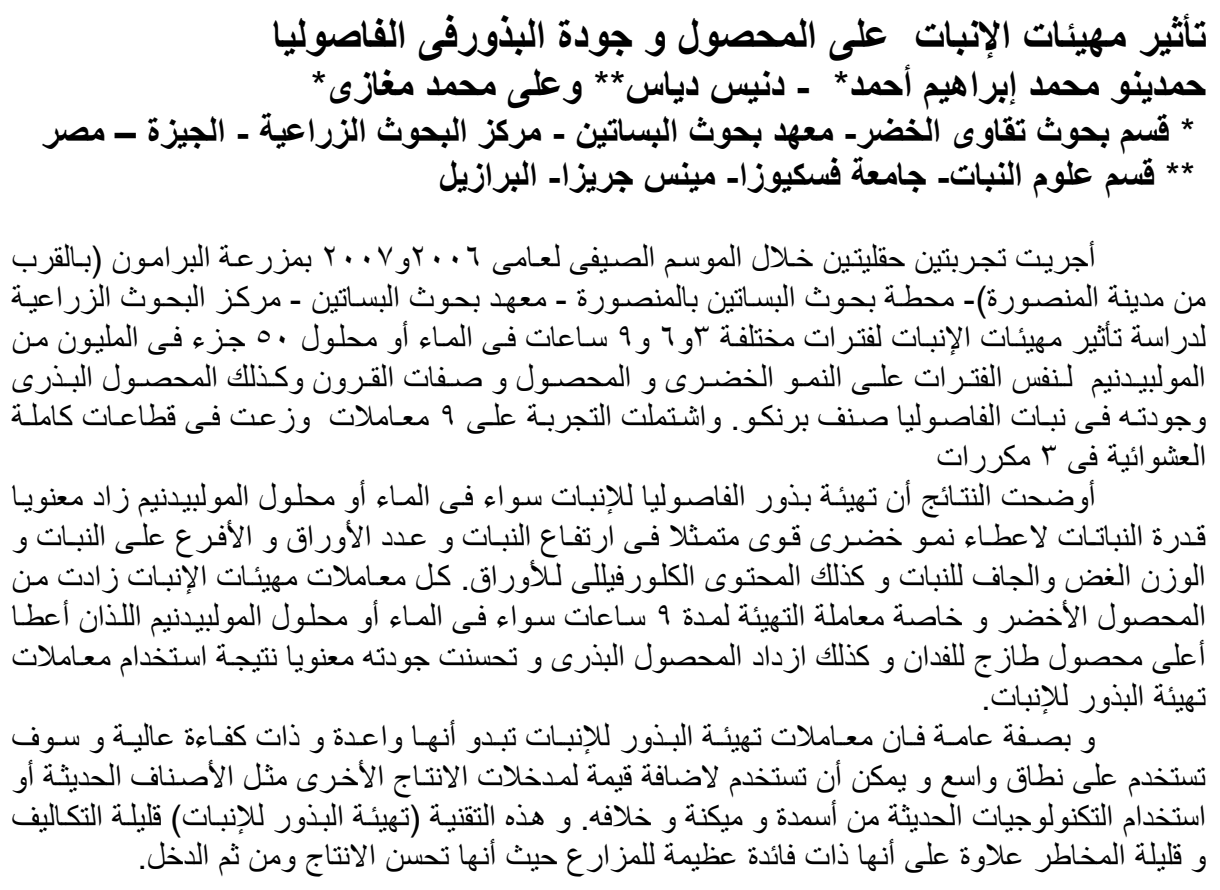


Ahmed, H. M.I. et al.

5032 
J. Agric. Sci. Mansoura Univ., 34 (5): -5019 - 5031, 2009

Table (5): The effects of seed priming on bean seed yield and its quality during 2006 and 2007 seasons.

\begin{tabular}{|c|c|c|c|c|c|c|c|c|}
\hline Seasons & \multicolumn{4}{|c|}{2006} & \multicolumn{4}{|c|}{2007} \\
\hline Treatments & $\begin{array}{c}\text { Seed } \\
\text { Yield } \\
(\mathbf{k g} / \mathrm{fed})\end{array}$ & $\begin{array}{c}\text { Seed } \\
\text { Index } \\
(g)\end{array}$ & $\begin{array}{c}\text { Germination } \\
\text { Percentage } \\
\text { (\%) }\end{array}$ & $\begin{array}{c}\text { Mean } \\
\text { Germination } \\
\text { Time } \\
\text { (days) }\end{array}$ & $\begin{array}{c}\text { Seed Yield } \\
(\mathrm{kg} / \mathrm{fed})\end{array}$ & $\begin{array}{c}\text { Seed } \\
\text { Index } \\
(g)\end{array}$ & $\begin{array}{c}\text { Germination } \\
\text { Percentage } \\
\text { (\%) }\end{array}$ & $\begin{array}{c}\text { Mean } \\
\text { Germination } \\
\text { Time } \\
\text { (days) }\end{array}$ \\
\hline Control & $716 \mathrm{i}$ & $26.0 \mathrm{~b}$ & $85.0 \mathrm{f}$ & $3.25 \mathrm{a}$ & $680 \mathrm{f}$ & $25.9 \mathrm{~d}$ & $87.0 \mathrm{e}$ & $3.30 \mathrm{a}$ \\
\hline Priming in water for $\mathbf{3} \mathrm{h}$. & $1010 \mathrm{~h}$ & $30.0 \mathrm{a}$ & $88.0 \mathrm{e}$ & $3.00 \mathrm{~b}$ & $946 \mathrm{e}$ & $29.9 \mathrm{c}$ & $88.0 \mathrm{~d}$ & $2.95 \mathrm{~b}$ \\
\hline Priming in water for $6 \mathrm{~h}$. & $1077 \mathrm{~g}$ & $31.1 \mathrm{a}$ & $90.0 \mathrm{c}$ & $2.44 \mathrm{c}$ & $1010 \mathrm{~d}$ & $31.3 \mathrm{~b}$ & $92.0 \mathrm{a}$ & $2.50 \mathrm{~d}$ \\
\hline Priming in water for $9 \mathrm{~h}$. & $1213 \mathrm{c}$ & $32.1 \mathrm{a}$ & $88.0 \mathrm{e}$ & $2.50 \mathrm{c}$ & $1124 \mathrm{c}$ & $32.1 \mathrm{a}$ & $87.0 \mathrm{e}$ & $2.45 \mathrm{de}$ \\
\hline Priming in water for $12 \mathrm{~h}$. & $1146 \mathrm{~d}$ & $31.9 \mathrm{a}$ & $89.0 \mathrm{~d}$ & $2.04 \mathrm{~d}$ & $1133 \mathrm{c}$ & $23.1 \mathrm{a}$ & $88.0 \mathrm{~d}$ & $2.10 \mathrm{~g}$ \\
\hline Priming in $50 \mathrm{ppm}$ Mo solution for $3 \mathrm{~h}$. & $1080 \mathrm{f}$ & $31.2 \mathrm{a}$ & $90.0 \mathrm{c}$ & $2.23 \mathrm{~d}$ & $1169 \mathrm{~b}$ & $31.2 \mathrm{~b}$ & $90.0 \mathrm{c}$ & $2.30 \mathrm{f}$ \\
\hline Priming in $50 \mathrm{ppm}$ Mo solution for $6 \mathrm{~h}$. & $1196 \mathrm{~d}$ & $32.0 \mathrm{a}$ & $91.0 \mathrm{~b}$ & $2.50 \mathrm{c}$ & $1129 \mathrm{c}$ & $32.1 \mathrm{a}$ & $90.0 \mathrm{c}$ & $2.73 \mathrm{c}$ \\
\hline Priming in $50 \mathrm{ppm}$ Mo solution for $9 \mathrm{~h}$. & $1285 \mathrm{a}$ & $32.1 \mathrm{a}$ & $90.0 \mathrm{c}$ & $2.12 \mathrm{~d}$ & $1216 \mathrm{a}$ & $32.1 \mathrm{a}$ & $91.0 \mathrm{~b}$ & $2.34 \mathrm{ef}$ \\
\hline Priming in $50 \mathrm{ppm}$ Mo solution for $12 \mathrm{~h}$. & $1282 \mathrm{~b}$ & $31.9 \mathrm{a}$ & $92.0 \mathrm{a}$ & $2.20 \mathrm{~d}$ & $1214 \mathrm{a}$ & $32.0 \mathrm{a}$ & $92.0 \mathrm{a}$ & $2.12 \mathrm{~g}$ \\
\hline
\end{tabular}


Ahmed, H. M.I. et al. 